\title{
反復性顔面神経麻痺について
}

\section{一メルカーソン・ローゼンタール症候群が疑われた症例 一}

$\begin{array}{ccr}\text { 岡山大学医学部麻醉科蘇生科 } & \text { 武田 } \\ \text { 東洋医学研究班 } & \text { 野上 直樹 } \\ & \text { 内田 輝和 }\end{array}$

\section{〔はじめに〕}

末梢性顔面神経麻瘒は、一般に片側性、単発 性のものがほとんどであるが、希に両側性、あ るいは再発を絽り返すむのがある。

今回、同側の末梢性顔面神経麻痺を 5 回繰り 返した症例を経験した。治療においては、星状 神経節ブロック（以下 S G B と略す）、投薬及 び低周波置針療法（以下E A P と略す）が主体 となったが、症状の改善が見られず、全良導絡 調整を併用したところ、良好な結果を得たので、 若干の文献的考察を加えて報告する。

May Score

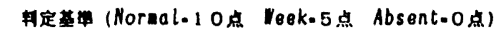

\begin{tabular}{|ll|}
\hline \multicolumn{1}{|c}{} & 目 \\
\hline 1 Tone & 6 Grin \\
2 Vrinkle Forehead & 7 Whistle \\
3 Close Eyes Tightly & 8 Blov Out Cheeks \\
4 Blink & 9 Depress Lover Lips \\
5 Vrinkle Nose & 10 Tense Neck \\
\hline
\end{tabular}

なお、今回の症例の効果判定は、May Score にて行った。

May Score はスライドのごとく、10項目に 分け、ほぼ正常10点、部分麻瘴 5 点、高地麻㿁 0 点として 100 点満点とした。

[ 店 ]

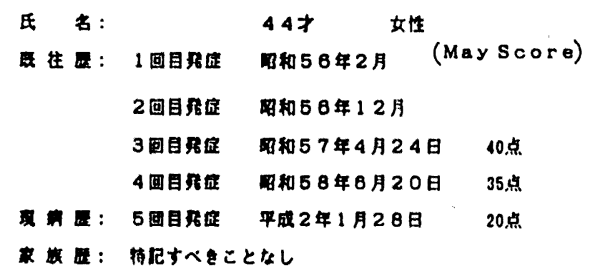

[症例]

氏名 :

年齢 : 44歳 女性

[既往歴]

第 1 回目の麻疸は、昭和 56 年 2 月に出現し、 近医耳鼻科にて治療を受け、約 6 力月で治癒し た。しかし同年12月に 2 回目の麻渒が出現した。

近医にて、S G Bなどの治療を受け、約 3 力 月で麻痺は多少残存したが、かなり改善した。

その後昭和 57 年 4 月 24 日に 3 回目の麻痷が出 現し、同様の治療を受けた。しかし、改善が認 められず、手術を勧められたが拒否し、同年 5 月24日、岡山大学附属病院麻酔科蘇生科を受診 した。

当科にて S G B、EAPを行い、約 4 力月で 麻痺は多少残存したが、May Score は40点 $\rightarrow$ 80点まで改善され、患者の希望により治療を打 ち切った。

昭和58年 6 月 20 日に、 4 回目の麻痺が出現し た。当科にて同様の治療を行い、約 4 力月で May Score は、35 $\rightarrow 60$ 点まで改善され、この 時点で同様に、患者の希望により治療を打ち切った。 その他、特記すべきことはなかった。

\section{[現病歴]}

平成 2 年 1 月 28 日に 5 回目の麻症が出現し、 2 月 2 日当科に来院。

May Score は20点であった。

また、発作性・回転性の目まいが強かったた め、即日入院となった。その他、右㚘頁部に軽い 浮腫が認められた。聴力低下、耳鳴りなどの症 
状はなかった。C. T. M. R . I . の検査で は、脳障害は認められなかった。その他、血液 生化学検査などあ、同様であった。

[家族歴]

特記すべきことはなかった。

[治方法]

1. S a B …....28 28 回

2. ヒタミン教与

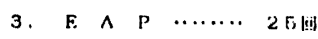

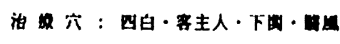

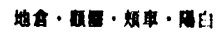

告用非：ヒイリン化成 40n20月

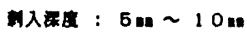

- * : ノィンフター W-4

成议 : $3 \mathrm{~Hz}$

- 10 年闻通

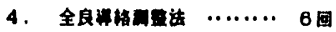

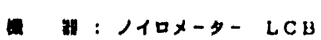

〔治療方法および経過〕

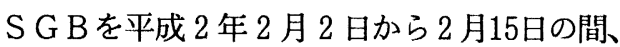
1 日 2 回のベースで計28回行った。

また、同時期にビタミン剤の投与を合わせて 行った。

E A P は、患側の四白・客主人・下関・毉風・ 地倉・顴髎頬車・陽白の 8 ポイントとし、 2 月 7 日から 4 月 25 日の間は週 2 回、5 月10日か ら 7 月 6 日の間は週 1 回のペースで、合計 25 回 行った。

使用針は、セイリン化成ステンレス針 $40 \mathrm{~mm} 20$ 号を用い、深さは $5 \sim 10 \mathrm{~mm}$ 刺入し、ノイロ医科 工業社製ノイロソフター・W -4 にて、 $3 \mathrm{~Hz}$ の連続波を10分間通電した。

ノイロ医科工業社製ノイロメーター・ L C $\mathrm{B}$ にて、全良導絡調整療法を 6 回行った。

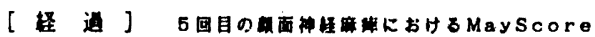

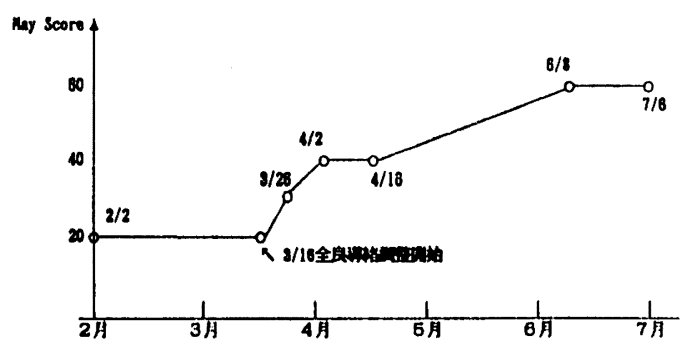

2 月15日 May Score は20点と改善は認めら れなかったが、目まいなどの症状は消失したた め退院となった。以後、外来にて E A P み治 療を継続したが、改善が認められなかったので、 3 月16日より全良導絡調整のため、生理的範囲 を逸脱した興奮点・抑制点に、12Vの直流 7 秒 通電を計 6 回行った。

4 月に入り、May Score は40点に改善された。

6 月、May Score は60点に改善され、7月 6 日、その後、変化がなかったため患者の希望 により治療を打ち切った。

[毒察I]

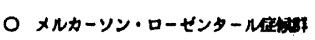

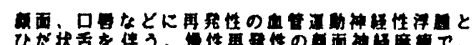

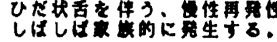

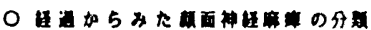

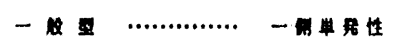

特 兵

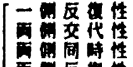

[考察]

この症例では

- 5 回の末梢性の反復性顔面神経麻痺

- 右頬部の軽度の浮腫

・ひだ状舌

により、メルカーソン・ローゼンタール症候群 が疑われたが、病理学的には、口唇の肉芽腫性 病変、また家族的因子などが認められなかった ため、今回は証明されなかった。

顔面神経麻痖の経過から見た分類としては、 一般型と特異型に分けられる。

一般型は一側単発性、特異型は一側反復性、 両側交代性、両側同時性、両側反復性があり、 この症例は一側反復性であった。

\section{[寿察 II]}

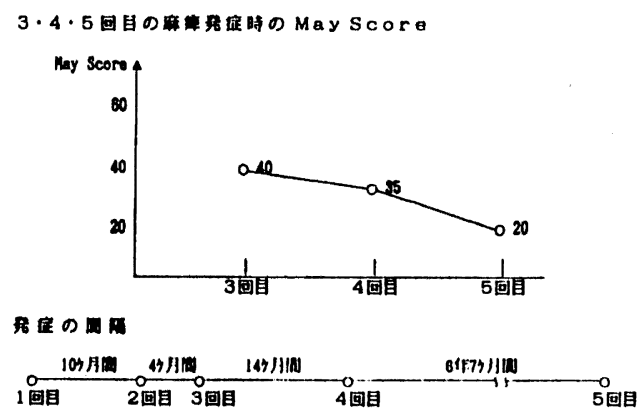


また、再発するたびに、初期の May Score は低下する傾向にあった。

麻瘒治療に E A P と S G B を併用することに より、再発までの期間の延長が示唆された。

顔面神経麻痷の一般的な治療の目的としては、

1. 神経浮腫を軽減し、管内圧を低下させ、 神経变性の進行を防止する。

2、神経を賦活させ、神経の再生を促進させ る。

3．顔面筋の萎縮を防ぐ。

などが考えられるが、E A P による治療では、 軸索反射による刺入局所の血流量の増加、深部 温の上昇などの効果が期待でき、また、三叉神 経の知覚枝を介しての刺激は、局所の自律神経 系、特に交感神経系の変化として血管運動神経 に影響を与えると考えられる。また、顔面筋の 萎縮を防ぐことに関しては、モーターポイント 刺激による筋収縮運動などが考えられる。全良 導絡調整については、6面のノイロメトリーの 特集、中谷らのいう顔面神経麻神の特徽的パター ンは認められなかった。しかし、慢性疾患や難 治性疾患においては、全良導絡調整の必要性が 指摘されており、今回も全良導絡調整を行うこ とによって自然治癒力が上がり、良好な結果が 得られたと推測される。

[ 䊅䛻]

1)再年するたひに、May Scoreは低下していた。

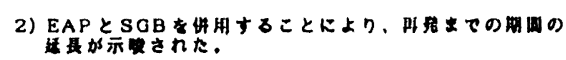

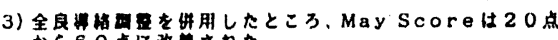
加60点改淟された。

[結語]

1) 再発するたびに May Score は低下してい た。

2）E A P と S G B を併用することにより、再 発までの期間の延長が示唆された。

3 ）全良導絡調整を併用したところ、May Score は20点 $\rightarrow 60$ 点に改善された。

なお、現時点での再発は認められておりませ ん。

この発表を行うにあたり、ご想切なるご指導 を頂いた岡山大学医学部麻酔下蘇生科の古谷助
教授並びに石津先生、その他東洋医学研究班の 諸先生方に厚く御礼申し上げます。

\section{参考文献}

1 ）柳原尚明他：両側性及び反復性顔面神経麻 疸の統計的観察、耳鼻臨床、P.1678. (1973. 11)

2) 小田博久: 顔面神経麻瘦、医道の日本 528 : P.21 (1988.8)

3) JOHNS : Vol. 4 、No. 7 : P.929. (1988)

4 ）代田文誌: 治験例を主とした針尒治療の実 際 (上)、創元社、P.376

5 ）木下晴都：最新針尒治療学（下）、医道の 日本社、P.28

6) 上海中医学院編 : 針众学、刊々堂出版社、 P. 640

7 ）中谷義雄 他：昭和 49 年度厚生省科学技術 助成金による研究、4446例からの分析

（テ700 岡山市鹿田町 2-5-1

岡山大学医学部麻酔科蘇生科 一東洋医学研究班内） 